\title{
The Development of Higher Order Thinking Skills Evaluation Instrument in Poetry Writing Material for Vocational High School
}

\author{
Bakhtiar Rivai Matondang \\ Indonesian Language Education and Literature \\ State University of Medan \\ Medan, Indonesia \\ Corresponding email: bakhtiarrivai239@gmail.com
}

\author{
Syahnan Daulay \\ Indonesian Language Education and Literature \\ State University of Medan \\ Medan, Indonesia
}

\author{
Khairil Ansari \\ Indonesian Language Education and Literature \\ State University of Medan \\ Medan, Indonesia
}

\begin{abstract}
This study aims to develop an assessment tool based on Higher Order Thinking Skills (HOTS) for learning to write poetry. This type of research is research and development that refers to the development model of Borg and Gall. With subject matter experts, evaluation experts, Indonesian language teachers and students. The results of this study indicate that: (1) Validation of material experts includes the average content feasibility of $88.13 \%$ with good criteria, the average presentation feasibility of $88.54 \%$ with good criteria, and linguistic aspect with an average of $90,28 \%$ with very good criteria. (2) validation of multiple choice evaluation experts where it assessed the material aspect, construction and language obtained an average of $90.00 \%$ with very good criteria and validation evaluation expert description which assessed material, construction and language aspects gained an average of $89.58 \%$ with good criteria. The practicality of the assessment instrument was concluded based on the teacher's response and student response; (3) the teacher's response gained an average of $84.17 \%$. Student trials of HOTS-based assessment instrument on individual tests obtained 73.61\% with sufficient criteria, (4) small group trials obtained an average of 83.49 with good criteria. (5) Limited field trials obtained an average of $90.69 \%$ with very good criteria. Likewise, the results of trials of HOTS-based assessment instrument for students obtained an average of 68 with sufficient category. Thus, it can be concluded that the instrument for testing higher order thinking skills in Vocational High School Budisatrya Medan is of sufficient quality.
\end{abstract}

Keywords - assessment instrument; higher order thinking skills; poetry writing

\section{INTRODUCTION}

Properly conducted assessments will ensure an improvement in the quality of learning. Assessment of learning outcomes is an integral part of the whole process. Nurgiyantoro (2012) revealed that, all components of the learning system influence each other and determine one another thus if all components run well, it will definitely produce maximum output [1].

Early stage observations made on Indonesian language teacher Rika Anggraini, S.Pd. in Budisatrya Medan, explained that the assessment instrument carried out by the teacher was only on the assessment technique chosen in accordance with the characteristics or abilities of students. Another fact is that most teachers in appraisal of practical assignments or demonstrating something do not provide an assessment based on the performance carried out. This is consistent with the results of the study by Novalia (2015) "[2]. who explained that the reason teachers do not carry out performance assessments is because teachers do not understand performance appraisal, the assessment of students' performance is very difficult to implement in schools because teacher attention is focused on all students with various abilities. Even though the average number of students in most classes in Indonesia is very large.

The material that must be mastered by students in curriculum 2013 class X is learning to write poetry. Siswanto (2011) said that, poetry is a literary form that expresses the thoughts and feelings of poets imaginatively and is composed by concentrating physical structure and inner structure [3]. Poetry is the most concise and concentrated form of literature, at most saying the fewest words. Learning to write poetry which aims to explore and develop the basic competencies of students in appreciating literature, also to train students' skills in exploring the values contained in poetry so that they can love poetry that ultimately they can create quality poems.

Realizing the importance of learning to write poetry for students, this learning needs serious attention. In the reality, namely in the Budisatrya Vocational School, shows that learning to write poetry in schools is still experiencing problems and tends to be avoided by students. This is caused by the lack of understanding of the values and other benefits that students can get when writing poetry. 
In the development of assessment instruments the teacher must make regularity questions that are in accordance with the questions grid. In Medan Budisatrya school the lattice of the question is only in the form of an essay while in the test it is not only essays but multiple choices as well. The grids that were made before must be in the form of multiple choices and essays.

The results of the analysis showed that the instruments in the student book were not adequate because each task was only 4 to 6 questions. The instruments used in cognitive assessment in the form of questions that tend to test more aspects of memory, while the questions that train students' higher order thinking skills were not widely available, so it is necessary to develop a higher order thinking skills assessment instrument. Thus, the higher order thinking skills assessment instrument developed will help students train their reasoning, analyzing, and deliver their opinions.

Minister of Education and Culture in Budiman (2014) mentions that future competition needs are required by Higher Order Thinking Skills critically, communication skills, and creative [4]. This is in line with the opinion Rofiah (2013) about the characteristics of 21 st century community skills published by the Partnership of 21st Century Skill identifying that learners in the 21 st century must be able to develop the competitive skills needed in the 21 st century focusing on developing Higher Order Thinking Skills [5]. Higher Order Thinking Skills (HOTS) is the ability to think critically, logically, reflective, metacognitive and creative thinking which is a higher order thinking skills that students must possess. Curriculum 2013 also requires metacognitive learning materials that require students to be able to predict, design, and estimate.

Based on the above problems, the writer wants to develop "test instruments to measure higher order thinking skills" students so that the questions made include analyzing (C4), evaluating (C5), and creating (C6) stages as well as to improve students' higher order thinking skills.

The purpose of this study is to develop the HOTS test instrument as an alternative instrument for assessing higherorder thinking skills in Indonesian language learning, (1) describing the development process of assessing poetry writing skills for higher-order thinking skills, (2) describing the feasibility of higher order thinking skills assessment-based poetry writing instrument. (3) describe the ability to understand poetry writing questions based on higher order thinking skills.

\section{METHOD}

This research method used Research and Deveplomend (R \& D) method. According to Sugiono (2010), Research and development methods are research methods used to produce certain products and test the effectiveness of certain products [6]. The subjects of this study were students in Medan class X Vocational High School Budisatrya 2018/2019 school year. The study was conducted from January to July 2018. This development research refers to the teaching material development model proposed by Borg and Gall. This study used two data collection techniques. Both techniques were nontest and tests. The instruments in this study were questionnaires and written tests. Questionnaire consists of evaluation expert validation questionnaire. The assessment instruments in this study were HOTS assessment instruments used in the development and testing stages. Quantitative data analysis in this study was divided into four, namely: feasibility assessment instrument, test characteristics of Higher Order Thinking, data analysis prerequisite test, and effectiveness test/hypothesis test.

\section{RESULTS AND DISCUSSION}

\section{A. The Process of Developing HOTS-Based Assessment Instruments}

The process of developing higher order thinking skillsbased assessment instruments showed that $81.25 \%$ of students were not familiar with higher order thinking skills assessment instrument. This shows students need higher order thinking skills assessment instruments in writing poetry. Furthermore, data obtained $87.50 \%$ of students stated that so far they only used assessment instruments that were already published by the Government without other handbooks. Subsequent data showed that $90,63 \%$ of students needed this assessment instrument.

The development process was carried out in stages. The first stage was to conduct problem analysis to gather information by building questionnaires to 2 teachers and 30 students. From the results of the questionnaire analysis distributed, it was revealed that most teachers and students needed an assessment instrument developed based on higher order thinking skills on poetry writing material as a means of learning individually.

The design of the next assessment instrument was based on an analysis of the problems that had been found before, namely by developing a higher order thinking skills-based poetry writing assessment instrument. Assessment instruments that have been compiled and validated and declared feasible, this product was tested on groups of individuals, small groups, and limited groups. Thus, the assessment instrument developed can be declared valid if it has met the criteria or score of the predetermined acquisition.

\section{B. Feasibility of HOTS-Based Assessment Instruments}

After the instrument has been developed, the next step was to test the appropriateness of the assessment instrument by validating by 2 material experts and 2 evaluation experts. Aspects of assessment included aspects of content feasibility, aspects of language worthiness, aspects of feasibility of presentation and from evaluation experts including material aspects, construction aspects and aspects of language. The aspect of content feasibility was obtained on average $88.13 \%$ with "good" category. Aspect of feasibility with presentation obtained an average $88.54 \%$ with "good" category. Linguistic 
aspect obtained an average $90.28 \%$ with the category "very good".

The results of evaluation experts' validation of multiple choice based on higher order thinking skills instruments showed that the average percentage was $90.00 \%$ with "very good" category. This is inseparable from the acquisition of scores in each sub-component of feasibility in the assessment instrument which included: a) material / substance, b) construction, and c) language.

\section{TABLE 1. VALIDATION OF EVALUATION EXPERTS ON MULTIPLE CHOICE FEASIBILITY}

\begin{tabular}{|c|c|c|c|}
\hline No & $\begin{array}{l}\text { Sub Component of } \\
\text { Assessment }\end{array}$ & Average $(\%)$ & Criteria \\
\hline 1 & Material /Substance & $87.50 \%$ & Good \\
\hline 2 & Construction & $88.75 \%$ & Good \\
\hline 3 & Language & $93.75 \%$ & Very good \\
\hline \multicolumn{2}{|r|}{ Average } & $90.00 \%$ & Very Good \\
\hline
\end{tabular}

The average percentage results from the overall feasibility aspect of the description assessment instrument was stated as "good" with a total percentage of $89.57 \%$. The percentage results can be seen in the table below.

\section{TABLE 2. VALIDATION OF EVALUATION EXPERTS AGAINST ELIGIBILITY OF DESCRIPTIONS}

\begin{tabular}{|c|c|c|c|}
\hline No & $\begin{array}{l}\text { Sub Component of } \\
\text { Assessment }\end{array}$ & Average (\%) & Criteria \\
\hline 1 & Material /Substance & $87.50 \%$ & Good \\
\hline 2 & Construction & $90.63 \%$ & Very good \\
\hline 3 & Language & $90.63 \%$ & Very good \\
\hline \multicolumn{2}{|r|}{ Average } & $89.58 \%$ & Good \\
\hline
\end{tabular}

The results of this study are relevant to the study Malik (2018) which shows the results of the evaluation expert evaluation validation that HOTS assessment validation scores from each aspect, material aspect with a score of $4.16 \%=$ $83 \%$, aspect of construction with a score of $4.23 \%=85 \%$, and aspect of language with a score of $4.22 \%=84 \%$ [7]. The score shows qualitatively the instrument is categorized as very valid.

The results of the data obtained from the teacher stated that the assessment instrument in the form of higher order thinking skills poetry writing instruments for grade X students developed in accordance with the assessment of indicators in the statement as a whole with an average of $84.17 \%$ in the criteria of "good".

In accordance with the flow of Borg \& Gall Research and Development, the trials conducted on students included 3 stages, namely individual trials (3 students), small group trials ( 9 people), and limited group trials (30 students). In individual trials, an average score of $73.61 \%$ was obtained with the "sufficient" category. At this stage there were several writings that need to be fixed. In the small group trial, an average of $83.49 \%$ was obtained with "good" category. Then limited field trials obtained an average of $90.69 \%$ with the category "very good". Empirically graphs can be seen in the following figure.

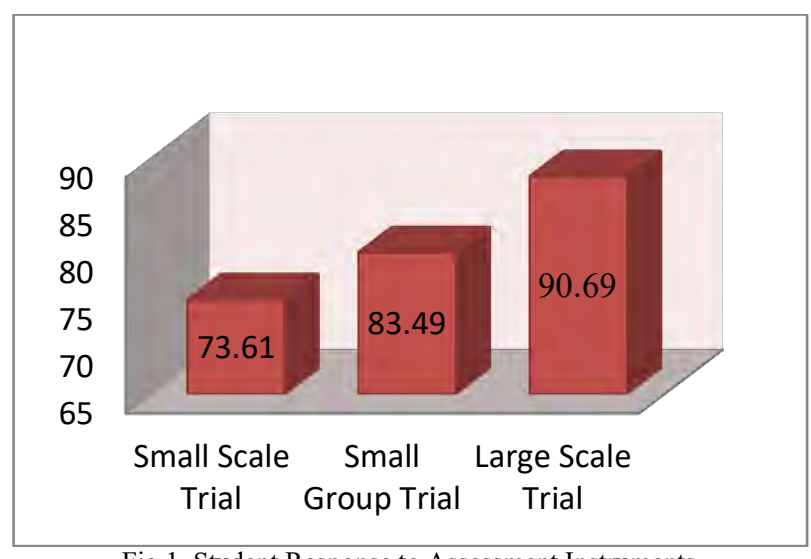

Fig 1. Student Response to Assessment Instruments

Based on these data, it can be concluded that higher order thinking skills-based assessment instruments can be used by teachers and students in terms of ease of use, timeliness, attractiveness.

\section{Students' Ability to Understand HOTS Questions}

The response of students' answers at the development stage was carried out by validity analysis empirically, which included the validity of test items, reliability, difficulty level, distinguishing power, and deception function. Based on the calculation, it showed that multiple choice questions on activity 1 amounted to 15 items and descriptions totaling 5 items, then in multiple choice questions activity 2 totaling 10 items and a description of 5 items of questions then stated that all the multiple choice questions and descriptions was valid because $t$-count $>$ r-table. The level of reliability of description in activity 1 was reliable with a value of 0.4287 with the level of interpretation "sufficient" while in activity 2 it was reliable with a value of 0.4131 with the level of interpretation "sufficient". Test items can be said to be good if the test items had a level of difficulty in inverval $0.31-0.70$. The following results of the level of difficulty analysis of the instrument of higher order thinking skills in activity 1 obtained an average score of difficulty 0.60 with the criteria of "medium" then in activity 2 obtained an average score of difficulty 0.60 with the criteria "medium". The items about the test instrument for higher order thinking skills can be said to be good if the items of the test had the least discriminating power 0.20. All questions had a distinguishing value of $>0.20$, this indicates that the items had a good distinguishing power.

In the field trial phase the researcher also tested the level of students' understanding ability to see the level of effectiveness of assessment instrument. Akker (1999) stated that "effectiviness refer to the extent that the experiences and outcomes with the intended aims" [8]. Students' understanding of higher order thinking skills of poetry writing assessment instruments is in sufficient criteria, this can be seen from the final assessment instrument with an average value of 6.8 . 
After testing, students' understanding of higher order thinking skills-based poetry writing assessment instruments received sufficient criteria, this can be seen from the final assessment instrument with an average score of 6.8. Based on the description above it is known that students have difficulty understanding high-thinking questions. Therefore, this assessment instrument can be used by teachers as a learning resource so that students are required to think highi.

\section{CONCLUSION}

Based on the objectives, the results of the research on the development of a higher order thinking skills-based poetry writing assessment instrument in the tenth grade students of Budisatrya Vocational High School Medan presented earlier are outlined below.

1. The results of developing a higher order thinking skills poetry writing assessment instrument based on needs analysis stated that the development of a higher order thinking skills-based poetry writing assessment instrument is needed by teachers and students in the learning process to improve the quality of learning and harmonize learning objectives with the latest curriculum provisions by the government and add student interest in learning.

2. The level of feasibility of HOTS-based assessment instrument based on the results of this study shows: (a) Validation of material experts after being combined with material experts 1 and 2 in assessing the feasibility of the content in good criteria $(88.13 \%)$, presentation eligibility is in good criteria $(88,54 \%)$ and language feasibility is in very good criteria $(90.28 \%$ ). (b) Validation of evaluation experts after being combined with evaluation experts 1 and 2 in multiple choice instrument validation assessments is in very good criteria $(90 \%)$, in instrument validation assessment the description is in good criteria $(89.58 \%)$.

3. The results of the ability to understand the questions of poetry writing assessment instruments based on higher order thinking skills (HOTS) students obtained an average score of 6.8 with sufficient category. Thus it can be stated that the instrument of assessment of higher order thinking skills in students of Medan Budisatrya Vocational School is of sufficient quality.

\section{REFERENCES}

[1] Nurgiyantoro, B., Penilaian Pembelajaran Bahasa. Yogyakarta: Gadjah Mada University Press, 2012, pp. 5

[2] Novalia, R., Fadiawati, N., and Rosilawati, I., "Pengembangan Instrumen Asesmen Kinerja pada Praktikum Pengaruh Konsentrasi terhadap Laju Reaksi”. Jurnal Pendidikan dan Pengajaran Kimia. Vol. 4 pp. 568-580, 2015.

[3] Siswanto. W., Pengantar Teori Sastra. Jakarta: Grasindo, 2011, pp. 108.

[4] Budiman, A. and Jailani, "Pengembangan Instrumen Asesmen Higher Order Thinking Skill (HOTS) Pada Mata Pelajaran Matematika SMP Kelas VIII Semester 1". Jurnal Riset Pendidikan Matematika, vol. 1, pp. 139-151, 2014.

[5] Rofiah, Emi, "Penyusunan Instrumen Tes Kemampuan Berpikir Tingkat Tinggi Fisika Pada Siswa SMP”. Jurnal Pendidikan Fisika, vol. 1, pp. 17-22, 2013.
[6] Sugiono, Metode Penelitian Pengembangan. Bandung: Alfabeta, 2010, pp. 407.

[7] Malik, A.,Rosidin,U., and Ertikanto, C., "Pengembangan Instrumen Assemen HOTS Fisika SMA Menggunakan Model Inkuiri Terbimbing". Jurnal Lentera Pendidikan Pusat Penelitian LPPM UM METRO, 2018, pp. .

[8] Akker J. V. D., "Principle And Methods Of Development Research". In $\mathrm{J}$ van den akker, R.Branch, K.Gustafson, Nieven, and T.Plomp (eds), Design Approaches And Tools In Education And Training. Dortrech: kluwer academy publishers, 1999, pp.10. 